INOBIS: Jurnal Inovasi Bisnis dan Manajemen Indonesia

Volume 2, Nomor 1, Desember 2018

Rois Arifin; Hadi Sunaryo

\title{
Tinjauan Empiris Tentang Orientasi Kewirausahaan Bagi Pengusaha Perempuan Di Kota Malang
}

\author{
Rois Arifin \\ Fakultas Ekonomi, Universitas Islam Malang \\ roisarifin18@yahoo.co.id \\ Hadi Sunaryo \\ Fakultas Ekonomi, Universitas Islam Malang \\ hadifeunisma@gmail.com
}

\begin{abstract}
Abstrak
Penelitian ini mengulas tentang orientasi kewirausahaan pengusaha perempuan di Kota Malang. Telaah konsep tentang orientasi kewirausahaan diperdalam dengan membentuk model pengukuran yang mengadaptasi dari penelitian sebelumnya. Model yang telah dibentuk diuji dan dianalisis melibatkan 71 pengusaha perempuan di Kota Malang yang menjadi responden dalam penelitian. Hasil penelitian mengindikasikan bahwa pengusaha perempuan lebih menganggap penting sikap proaktif sebagai bentuk terpenting dari orientasi kewirausahaan. Sementara fakta di lapangan mengungkap orientasi kewirausahaan bagi pengusaha perempuan lebih cenderung ditunjukkan oleh sikap pengambilan risiko. Diskusi tentang temuan penelitian mengarahkan kepada peran dari tipologi usaha yang dijalankan pengusaha disinyalir mempunyai implikasi penting pada orientasi kewirausahaan yang dimiliki oleh pengusaha perempuan. Selain itu pentingnya pengusaha perempuan memfokuskan pada keinovasian untuk menunjang orientasi kewirausahaannya menjadi lebih kuat dan mapan.
\end{abstract}

Kata Kunci : Orientasi Kewirausahaan, Keinovasian, Proaktif, Pengambilan risiko, Pengusaha Perempuan.

\section{Pendahuluan}

Pemberdayaan usaha kecil dan menengah (UKM) merupakan hal yang krusial bagi peningkatan perekonomian Indonesia, meski masih tidak selaras dengan tingkat daya saing yang menunjukkan tingkat daya saing Indonesia dalam persaingan global masih belum maksimal. Selain itu pemberdayaan UKM bersifat sangat strategis, mengingat potensinya yang besar dalam menggerakkan kegiatan ekonomi masyarakat, sekaligus merupakan sumber pendapatan sebagian besar masyarakat dalam meningkatkan kesejahteraannya.

Keberhasilan kinerja usaha kecil dapat ditentukan oleh orientasi kewirausahaan (entrepreneurial orientation). Proses kewirausahaan dipandang mempunyai komponen sikap dan perilaku (Lukiastuti, 2012), melihat bentuk sikap dalam kewirausahaan berkenaan dengan kemauan individu atau organisasi untuk mendapatkan peluang-peluang baru dan untuk mengambil tanggungjawab yang diperlukan untuk mempengaruhi perubahan yang kreatif. Mempertimbangkan pentingnya proses pada kewirausahaan telah dikenali dalam kajian strategis dalam sebuah entitas usaha dan atau bisnis (Mintzberg, 1973; Covin dan Slevin, 1989, 1991), maka konsepsi entrepreneurial orientation merupakan solusi yang relevan dan dipostulasikan berdampak positif bagi kinerja usaha kecil menengah (Hughes dan Morgan, 2007; Lukiastuti, 2012). Orientasi kewirausahaan (EO) yang mengacu orientasi strategis 
INOBIS: Jurnal Inovasi Bisnis dan Manajemen Indonesia

Volume 2, Nomor 1, Desember 2018

Rois Arifin; Hadi Sunaryo

perusahaan (Covin et al., 2006), menangkap aspek kewirausahaan spesifik gaya pengambilan keputusan, metode, dan praktik (Wiklund dan Shepherd, 2005). Sementara sebagian besar studi kewirausahaan menganggap orientasi kewirausahaan menjadi konsep kesatuan (Covin dan Slevin 1989; Wiklund 1999). Gagasan konsep faktor tunggal dari orientasi kewirausahaan juga telah diperiksa dalam beberapa studi, terutama berkaitan dengan ketiga dimensi dari orientasi kewirausahaan yang dapat bervariasi secara independen dari satu dengan yang lainnya (Krauss et al 2005; Lumpkin dan Dess 1996;Lyon et al., 2000).

Meskipun begitu, Pratono dan Mahmood (2016) meyakini bahwa turbulensi yang terjadi pada lingkungan memungkinkan seuatu usaha dapat memprediksi preferensi lingkungan, memanfaatkan inovasi baru dan mengambil lebih banyak risiko. Selama periode turbulensi lingkungan yang ekstrem, wirausaha mungkin lebih menghindari risiko untuk secara efektif mengelola preferensi pasar yang tidak dapat diprediksi. Oleh karenanya kondisi seperti ini mendorong kebutuhan tentang sumber daya lebih besar, dengan upaya keras bagi UKM mempertimbangkan keterbatasan sumber daya yang dimiliki, terutama untuk UKM yang dikelola oleh pengusaha perempuan.

Di Indonesia, kewirausahaan perempuan menghadapi situasi yang sama dengan perempuan dalam lingkungan dan peran kewirausahaan dalam lingkungan yang sama. Pada dasarnya usaha kecil menengah yang dikelola oleh perempuan memberikan kontribusi yang sangat strategis meskipun di sisi lain dipandang masih belum seimbang dengan pengakuan yang diperoleh baik dari pemerintah maupun keluarga (Wicaksono dan Nuvriasari, 2012). Persoalan daya saing UKM perlu mendapat perhatian dari pemerintah, masyarakat bisnis, termasuk kalangan akademisi untuk memecahkannya, terutama unuk UKM yang dikelola oleh pengusaha perempuan. Hatta (2014) menjelaskan bahwa orientasi kewirausahaan dipandang sebagai spearhead (pelopor) untuk mewujudkan pertumbuhan ekonomi usaha yang berkelanjutan dan berdaya saing tinggi.

Covin dan Wales (2012) telah mengulas konsep orientasi kewirausahaan serta dasar teori pengukuran untuk tujuan mengenalkan pemahaman umum tentang isu utama yang terkait dalam pengukuran orientasi kewirausahaan. Perhatian khusus diberikan pada hal-hal seperti apakah orientasi kewirausahaan dinilai paling tepat meskipun model pengukuran formatif atau reflektif dan keterbatasan berbagai model pengukuran ketika konseptualisasi tertentu dari orientasi kewirausahaan digunakan oleh peneliti. Hasil penelitian terdahulu seperti Wiklund dan Shepherd (2005) mengidentifikasi hubungan positif antara orientasi kewirausahaan dan kinerja bisnis. Hal ini menunjukkan pentingnya peran orientasi kewirausahaan dalam menunjang kinerja bisnis. Tetapi tidak banyak penelitian yang mengulas tentang orientasi kewirausahaan pada usaha kecil menengah yang dikelola oleh pengusaha perempuan.

Untuk memberikan pemahaman yang lebih lengkap tentang bagaimana orientasi kewirausahaan dipersepsikan oleh pengusaha perempuan, maka penelitian ini bertujuan untuk memperluas pemahaman tentang orientasi kewirausahaan dalam cakupan usaha kecil menengah. Hal ini akan membawa ke arah perluasan selanjutnya dari teori tentang orientasi kewirausahaan. Sebagaimana diungkapkan oleh Miller (2011) bahwa dorongan penelitian diarahkan untuk menganalisis dimensi orientasi kewirausahaan dan juga keseluruhan dari orientasi kewirausahaan dengan menunjukkan bahwa "dalam beberapa konteks penelitian, yang terbaik dari keduanya (multidimensional dan atau unidimensional) mungkin memerlukan analisis tambahan yang dapat menyajikan hasil untuk konstruksi dan untuk masing-masing komponen dari orientasi kewirausahaan itu sendiri”. Oleh karena itu isu utama tentang bagaimana UKM dikelola oleh pengusaha perempuan mendorong pentingnya tujuan utama dari penelitian ini dilakukan, yakni untuk menjelaskan potensi atau permasalahan 
INOBIS: Jurnal Inovasi Bisnis dan Manajemen Indonesia

Volume 2, Nomor 1, Desember 2018

Rois Arifin; Hadi Sunaryo

tentang kewirausahaan yang tersembunyi dan belum terungkap dari UKM yang dikelola pengusaha perempuan. Dengan menelaah lebih mendalam tentang orientasi kewirausahaan akan membawa kepada bagaimana hal ini dapat dikembangkan dan dimanfaatkan untuk pengembangan UKM di Kota Malang.

\section{Landasan Teori dan Pengembangan Hipotesis}

Orientasi kewirausahaan (EO) telah menjadi topik pembicaraan ilmiah dalam domain kewirausahaan dan strategis selama beberapa dekade (Lomberg et al., 2016). Dengan demikian, terlihat hampir tidak sesuai untuk menunjukkan bahwa penelitian di wilayah orientasi kewirausahaan tersebut sekarang sedang lepas landas (Covin dan Lumpkin, 2011). Namun, seperti yang diungkapkan oleh data publikasi yang dirangkum pada Covin dan Lumpkin (2011) agar teori dan penelitian tentang orientasi kewirausahaan dapat diarahkan lebih maju tidak hanya dalam hal jumlah publikasi tetapi juga dalam kaitannya dengan kredibilitas dan dampak ilmiah secara keseluruhan, penting bahwa kesenjangan pengetahuan dan ambiguitas konseptual yang terkait dengan teori dan penelitian EO dapat dikenali dan ditangani.

Mintzberg (1973) mengungkapkan bahwa dalam berwirausaha, strategi pembuatannya didominasi oleh pencarian aktif baru kesempatan dan juga lompatan dramatis ke depan dalam menghadapi ketidakpastian. Sementara Miller dan Friesen (1982) menjelaskan model kewirausahaan berlaku untuk usaha yang berinovasi dengan berani dan teratur saat mengambil risiko yang cukup besar dalam strategi produk untuk bersaing dalam pasar. Sementara Voss, Voss, dan Moorman (2005) menjelaskan orientasi kewirausahaan sebagai disposisi tingkat usaha untuk terlibat dalam perilaku (yang mencerminkan pengambilan risiko, inovasi, proaktif, otonomi, dan agresivitas kompetitif) yang menyebabkan perubahan organisasi atau pasar.

Orientasi kewirausahaan sering dipandang mempunyai keterkaitan dengan aspek psikometrik yang dilihat dari inovasi, sifat proaktif dan keberanian mengambil resiko yang dimiliki oleh usaha kecil dan mikro. Lumpkin dan Dess (1996) menjelaskan perbedaan antara konsep kewirausahaan (entrepreneurship) dan orientasi kewirausahaan (entrepreneurial orientation), dimana kewirausahaan lebih dikaitkan dengan pemain atau bermain bisnis baru dan sangat erat kaitannya dengan pertanyaan seperti "usaha apa yang akan dijalankan?". Orientasi kewirausahaan lebih dikaitkan dengan proses dalam kewirausahaan dan sangat erat dengan pertanyaan seperti "bagaimana membuat usaha-usaha baru menjadi berhasil?" (Richard, Barnett, Dwyer, \& Chadwick. 2004). Lumpkin dan Dess (2001) telah mendefinisikan orientasi kewirausahaan sebagai bentuk kegiatan entrepreneurial suatu entitas usaha yang berkaitan dengan inovasi produk, melakukan kegiatan yang beresiko dan yang pertama dalam memperkenalkan inovasi yang proaktif. Secara ringkas orientasi kewirausahaan merupakan salah satu orientasi stratejik dari suatu entitas usaha (perusahaan dan atau bisnis), salah satunya adalah mencakup aspek-aspek spesifik kewirausahaan seperti gaya pengambilan keputusan, metode, dan praktek-praktek usaha. Orientasi kewirausahaan merupakan kombinasi dari tiga dimensi inovasi (innovativeness), proaktif (proactiveness), dan pengambilan risiko (risk taking) (Miller dan Friesen,1982; Frank, Kessler, dan Fink, 2010). Ketiga dimensi tersebut merupakan ukuran yang populer untuk operasionalisasi dari orientasi kewirausahaan baik dalam literatur kewirausahaan maupun manajemen strategis yang dikembangkan oleh Covin dan Slevin $(1989 ; 1991)$, berdasarkan telaah awal dari Khandwalla (1977) serta Miller dan Friesen (1982). 
INOBIS: Jurnal Inovasi Bisnis dan Manajemen Indonesia

Volume 2, Nomor 1, Desember 2018

Rois Arifin; Hadi Sunaryo

Secara rinci Lumpkin dan Dess (1996) menguraikan bahwa :

1. Keinovasian adalah kecenderungan entitas bisnis atau usaha untuk menggunakan dan mendukung ide-ide baru, bereksperimen, dan melakukan proses kreatif yang memungkinkan keberhasilan dalam memperkenalkan produk atau jasa baru, hal-hal atau proses teknologi yang baru.

2. Proaktif adalah cara pandang kedepan atau pengambilan keputusan yang secara inisiatif dengan mengantisipasi dan mengejar peluang baru serta berpartisipasi dalam pasar yang muncul.

3. Pengambilan risiko adalah kemampuan aktif entitas bisnis atau usaha untuk mengejar peluang sekalipun peluang tersebut mengandung risiko serta ketidakpastian hasil.

Covin dan Wales (2012) menjelaskan orientasi kewirausahaan sebagai konstruksi laten bersifat terpisah dari ukurannya. Oleh karenanya peneliti tentang topik kewirausahaan ini mempunyai kebebasan memilih pendekatan pengukuran mana pun yang paling sesuai untuk tujuan penelitian, dengan mengetahui bahwa model pengukuran orientasi kewirausahaan unidimensional versus multidimensi konsisten dengan konseptualisasi konstruk orientasi kewirausahaan yang secara mendasar adalah berbeda. Terlepas dari hal tersebut, Covin dan Slevin (1991) telah menegaskan bahwa model perilaku kewirausahaan disarankan karena perilaku bukan atribut yang memberi makna pada proses kewirausahaan. Profil psikologis seseorang tidak membuat seseorang menjadi entrepreneur. Sebaliknya, pengusaha dapat mengetahui tentang konsepsi kewirausahaan melalui tindakan yang dilakukan . Singkatnya, perilaku adalah pusat dan elemen penting dalam proses kewirausahaan.

Dimensi pertama dari orientasi kewirausahaan adalah keinovasian. Keinovasian mengacu kepada kecenderungan suatu entitas bisnis atau usaha untuk dapat ikut serta dan mendukung gagasan baru, kebaruan (novelty), eksperimentasi, dan proses kreatif yang menghasilkan proses teknologi, jasa, dan produk baru (Lumpkin dan Dess,1996; Tan, 1996). Keinovasian menunjukkan keinginan perusahaan untuk meninggalkan teknologi dan praktik yang ada. Oleh karenanya, keinovasian mirip dengan suatu iklim, budaya atau orientasi dari usaha bukan mengacu kepada hasil.

Komponen selanjutnya dari orientasi kewirausahaan adalah proaktif (Proactiveness). Proaktif berkaitan dengan melihat ke depan (foward looking) dan upaya untuk dapat menjadi penggerak pertama. Covin dan Slevin (1991) secara spesifik menguraikan proactiveness sebagai kesempatan mencari, memandang ke depan yang melibatkan antisipasi dan bertindak untuk kebutuhan masa depan yang mungkin atau mungkin tidak terkait dengan lini operasi saat ini dan agresivitas dalam menanggapi tren dan permintaan yang sudah ada di pasar. Tujuan dari sikap proaktif untuk memperoleh keunggulan untuk membentuk lingkungan dengan memperkenalkan produk baru dalam persaingan yang akan datang (Lyon, Lumpkin dan Dess, 2000).

Komponen ketiga dari orientasi kewirausahaan adalah pengambilan risiko (risk taking). Pengambilan risiko didefinisikan sebagai sejauhmana para manajer berkeinginan membuat komitmen atas sumberdaya yang berisiko dan besar tetapi mereka memiliki peluang besar gagal (Miller dan Friesen, 1983). Lumpkin and Dess (2001) mengacu pada kecenderungan usaha untuk memasuki lingkungan yang tidak pasti dan tidak diketahui atau melakukan sebagian besar sumber daya untuk usaha dengan hasil yang juga masih tidak atau belum pasti. 
INOBIS: Jurnal Inovasi Bisnis dan Manajemen Indonesia

Volume 2, Nomor 1, Desember 2018

Rois Arifin; Hadi Sunaryo

\section{Metode Penelitian}

Penelitian ini dilakukan di Kota Malang, dengan menentukan sampel target adalah pengusaha perempuan yang mempunyai usaha kecil menengah di sektor produksi oleh-oleh di Kota Malang. Selanjutnya sebanyak 71 pengusaha perempuan yang bergerak di bidang bisnis produksi oleh - oleh dan suvenir di Kota Malang, telah menjalankan usahanya minimal selama 2 tahun dan memiliki karyawan dalam membantu kegiatan produksi, menjadi responden dalam penelitian.

Meskipun beberapa penelitian terdahulu telah banyak mengkaji tentang orientasi kewirausahaan, dalam penelitian ini mengadopsi pengukuran konstruk yang telah dikembangkan oleh Hughes dan Morgan (2007) serta Covin, Green, dan Slevin (2006). Sehingga kuesioner untuk dimensi orientasi kewirausahaan yang dikembangkan berlandaskan pada indikator yang telah diuraikan pada penelitian sebelumnya. Instrumen orientasi kewirausahaan yang dikembangkan dalam penelitian ini terdiri dari tiga dimensi, yakni (1) keinovasian (mean $=2,887 ; \mathrm{SD}=3,255$ ), (2) proaktif (mean=3,217; $\mathrm{SD}=3,422$ ), dan (3) pengambilan risiko (mean $=3,273 ; \mathrm{SD}=3,681$ ). Masing - masing indikator pada dimensi keinovasian, proaktif, dan pengambilan risiko diuraikan antara lain sebagai berikut :

Tabel 1

Operasionalisasi Konsep Dalam Penelitian

\begin{tabular}{|c|c|}
\hline Dimensi & Indikator \\
\hline $\begin{array}{l}\text { Keinovasian } \\
\text { (Innovativeness) }\end{array}$ & $\begin{array}{l}\text { - Melakukan inovasi dalam proses untuk pengelolaan usaha } \\
\text { - } \text { secara umum } \\
\text { - di usaha mikro kecil } \\
\text { - Perhatian yang tinggi dalam upaya pengembangan tehnik } \\
\text { - Aktif mencari metode baru yang digunakan dalam memproduksi } \\
\text { - } \text { secara efisien serta efektif } \\
\text { - Menjalankan usaha dengan kreatif }\end{array}$ \\
\hline $\begin{array}{l}\text { Proaktif } \\
\text { (Proactiveness) }\end{array}$ & $\begin{array}{l}\text { - Mendorong diri untuk dapat melakukan tindakan preventif } \\
\text { - Memperkuat lini organisasi dengan terus berkomunikasi dengan } \\
\text { para stakeholder baik internal maupun eksternal } \\
\text { - Mengakses informasi atau jalur peluang baru untuk } \\
\text { pengembangan usaha yang dijalankan } \\
\text { - Selalu mencoba untuk mengambil inisiatif dalam setiap situasi } \\
\text { - Selalu unggul dalam mengidentifikasi peluang. }\end{array}$ \\
\hline $\begin{array}{l}\text { Pengambilan } \\
\text { risiko } \\
\text { (Risk taking) }\end{array}$ & $\begin{array}{l}\text { - Mempunyai keberanian untuk mengambil risiko } \\
\text { - Secara pribadi dikenal sebagai sosok yang risk-taker } \\
\text { - } \text { Berani mengambil keputusan dengan probabilitas risiko yang } \\
\text { diketahui dengan jelas sebelumnya } \\
\text { - Mendorong orang-orang dalam bisnis untuk mengambil risiko } \\
\text { yang diperhitungkan dengan gagasan baru. } \\
\text { - Menekankan eksplorasi dan eksperimen untuk mendapatkan } \\
\text { peluang. }\end{array}$ \\
\hline
\end{tabular}

Sumber : adaptasi dari Hughes dan Morgan (2007) serta Covin, Green, dan Slevin (2006) 
INOBIS: Jurnal Inovasi Bisnis dan Manajemen Indonesia

Volume 2, Nomor 1, Desember 2018

Rois Arifin; Hadi Sunaryo

\section{Hasil dan Pembahasan}

Hasil uji validitas untuk masing-masing indikator pada instrumen penelitian diuji dari hasil perhitungan koefesien korelasi (rxy). Dengan diketahui besarnya keseluruhan koefisien korelasi yang diungkap mempunyai $r_{\text {hitung }}$ yang lebih besar dari 0,3 . Hal ini menunjukkan bahwa seluruh indikator dalam masing-masing konstruk untuk variabel yang diamati dalam penelitian ini dinyatakan valid. Hasil dari uji reliabilitas menunjukan nilai koefisien realibilitas Cronbanch's Alpha untuk keinovasian $(\alpha=0.719)$, proaktif $(\alpha=0.818)$, dan pengambilan risiko $(\alpha=0.898)$. Hasil menunjukan bahwa semua konstruk variabel mempunyai nilai Cronbach's Alpha diatas 0,60; maka disimpulkan bahwa instrumen yang digunakan dalam penelitian ini telah memenuhi kriteria reliabilitas.

Tabel 2

Koefisien Bobot Faktor Untuk Indikator Pada Dimensi Orientasi Kewirausahaan Perempuan

\begin{tabular}{|c|c|c|c|}
\hline Konstruk & Item & $\begin{array}{c}\text { Koefisien } \\
\text { Bobot } \\
\text { Faktor }\end{array}$ & Mean \\
\hline \multirow{5}{*}{ Keinovasian } & $\begin{array}{l}\text { Melakukan inovasi dalam proses untuk pengelolaan } \\
\text { usaha }\end{array}$ & 0,768 & 3,14 \\
\hline & $\begin{array}{l}\text { Melakukan perbaikan yang berkelanjutan dalam proses } \\
\text { produksi }\end{array}$ & 0,294 & 2,59 \\
\hline & $\begin{array}{l}\text { Perhatian yang tinggi dalam upaya pengembangan tehnik } \\
\text { atau metode }\end{array}$ & 0,344 & 2,66 \\
\hline & Aktif mencari metode baru & 0,914 & 3,00 \\
\hline & Menjalankan usaha dengan kreatif & 0,892 & 3,04 \\
\hline \multirow{5}{*}{ Proaktif } & $\begin{array}{l}\text { Mendorong diri untuk dapat melakukan tindakan } \\
\text { preventif }\end{array}$ & 0,775 & 3,54 \\
\hline & $\begin{array}{l}\text { Memperkuat lini organisasi dengan berkomunikasi } \\
\text { internal maupun eksternal }\end{array}$ & 0,772 & 3,15 \\
\hline & $\begin{array}{l}\text { Mengakses informasi atau jalur peluang baru untuk } \\
\text { pengembangan usaha }\end{array}$ & 0,754 & 3,27 \\
\hline & Selalu mencoba untuk mengambil inisiatif & 0,742 & 3,03 \\
\hline & Selalu unggul dalam mengidentifikasi peluang & 0,757 & 3,10 \\
\hline \multirow{5}{*}{$\begin{array}{c}\text { Pengambilan } \\
\text { Risiko }\end{array}$} & Mempunyai keberanian untuk mengambil risiko & 0,797 & 3,15 \\
\hline & Secara pribadi dikenal sebagai sosok yang risk-taker & 0,869 & 3,30 \\
\hline & Berani mengambil keputusan dengan probabilitas risiko & 0,851 & 3,28 \\
\hline & Mendorong orang dalam bisnis untuk mengambil risiko & 0,887 & 3,27 \\
\hline & $\begin{array}{l}\text { Menekankan eksplorasi dan eksperimen untuk } \\
\text { mendapatkan peluang }\end{array}$ & 0,811 & 3,37 \\
\hline
\end{tabular}

Sumber : Output Analisis Faktor (2018)

Hasil yang ditunjukkan oleh Tabel 2 mengindikasikan nilai koefisien bobot faktor dan varians yang dijelaskan untuk setiap dimensi yakni (1) keinovasian (berkisar dari 0,294 sampai dengan 0,914), kemudian (2) proaktif (berkisar dari 0,742 sampai dengan 0,772), serta (3) pengambilan risiko (berkisar dari 0,797 sampai dengan 0,887). Siginifikansi dari hasil dari factor loading untuk masing - masing indikator pada dimensi proaktif dan pengambilan risiko 
INOBIS: Jurnal Inovasi Bisnis dan Manajemen Indonesia

Volume 2, Nomor 1, Desember 2018

Rois Arifin; Hadi Sunaryo

adalah signifikan $(p<0.01)$. Sementara untuk dimensi keinovasian terdapat dua indikator yakni "melakukan perbaikan yang berkelanjutan dalam proses produksi" dan "perhatian yang tinggi dalam upaya pengembangan tehnik atau metode" ditemukan tidak mempunyai bobot faktor yang bermakna penting dalam merefleksikan dimensi keinovasian untuk orientasi kewirausahaan.

Dimensi keinovasian paling direfleksikan oleh indikator $\mathrm{X}_{1.4}$, aktif mencari metode baru $(\lambda=0,914)$. Sedangkan indikator yang paling rendah dalam merefleksikan dimensi keinovasian adalah $\mathrm{X}_{1.2}$, melakukan perbaikan yang berkelanjutan dalam proses produksi $(\lambda$ $=0,294)$. Dimensi proaktif paling direfleksikan oleh indikator $X_{2.1}$, mendorong diri untuk dapat melakukan tindakan preventif $(\lambda=0,775)$. Sedangkan indikator yang paling rendah dalam merefleksikan dimensi proaktif adalah $X_{2.4}$, selalu mencoba untuk mengambil inisiatif $(\lambda=0,742)$. Dimensi pengambilan risiko paling direfleksikan oleh indikator $X_{3.4}$, yakni mendorong orang dalam bisnis untuk mengambil risiko $(\lambda=0,887)$. Sedangkan indikator yang paling rendah dalam merefleksikan dimensi pengambilan risiko adalah $\mathrm{X}_{3.1}$, yakni indikator mempunyai keberanian untuk mengambil risiko $(\lambda=0,797)$.

Tabel 3

Koefisien Bobot Faktor Dan Mean Untuk Dimensi Dari Orientasi Kewirausahaan

\begin{tabular}{|l|c|c|l|l|}
\hline \multicolumn{1}{|c|}{ Dimensi } & $\begin{array}{c}\text { Koefisien } \\
\text { Bobot } \\
\text { Faktor }\end{array}$ & t-Statistic & Keterangan & Mean \\
\hline Keinovasian & 0,799 & 23,826 & Signifikan & 2,887 \\
\hline Proaktif & 0,856 & 33,005 & Signifikan & 3,217 \\
\hline Pengambilan Risiko & 0,840 & 23,898 & Signifikan & 3,273 \\
\hline
\end{tabular}

Sumber : Output Analisis Faktor (2018)

Tabel 3 menunjukkan hasil uji koefisien bobot faktor pada masing - masing dimensi orientasi kewirausahaan yakni dimensi keinovasian, proaktif, dan pengambilan risiko. Nilai $t$ statistic yang melebihi nilai kritis sebesar 1.96 dinyatakan signifikan dan sebaliknya. Berdasarkan Tabel 3 nilai $t$-statistic dari seluruh dimensi untuk variabel orientasi kewirausahaan menunjukkan kriteria signifikan (nilai t-statistic > 1.96). Maka dapat disimpulkan bahwa keinovasian, proaktif, dan pengambilan risiko merupakan hal - hal yang bermakna penting dalam merefleksikan orientasi kewirausahaan pengusaha permpuan. Menurut persepsi pengusaha perempuan di Kota Malang, hal yang paling penting dalam merefleksikan orientasi kewirausahaan adalah sikap proaktif. Meskipun hal ini bertolak belakang dengan persepsi faktual dari pengusaha perempuan yang merasa lebih berani untuk mengambil risiko dalam orientasi menjalankan usahanya.

Selanjutnya berdasarkan hasil yang tertuang pada Tabel 3 maka dilakukan pembuktian hipotesis yakni sebagai berikut:

Koefisien bobot faktor dari keinovasian atas orientasi kewirausahaan ditemukan bernilai signifikan sebesar 0,799. Koefisen bobot faktor tersebut dikategorikan signifikan pada level 0,05 karena nilai t-Statistik lebih besar dari 1.96 yakni sebesar 23,826. Berdasarkan temuan tersebut maka Hipotesis 1 dalam penelitian ini diterima, yang berarti bahwa keinovasian merupakan refleksi penting dari orientasi kewirausahaan bagi pengusaha perempuan di Kota Malang.

Koefisien bobot faktor dari proaktif atas orientasi kewirausahaan ditemukan bernilai signifikan sebesar 0,840. Koefisen bobot faktor tersebut dikategorikan signifikan pada level 
INOBIS: Jurnal Inovasi Bisnis dan Manajemen Indonesia

Volume 2, Nomor 1, Desember 2018

Rois Arifin; Hadi Sunaryo

0,05 karena nilai t-Statistik lebih besar dari 1.96 yakni sebesar 33,005. Berdasarkan temuan tersebut maka Hipotesis 2 dalam penelitian ini diterima, yang berarti bahwa proaktif merupakan refleksi penting dari orientasi kewirausahaan bagi pengusaha perempuan di Kota Malang.

Koefisien bobot faktor dari pengambilan risiko atas orientasi kewirausahaan ditemukan bernilai signifikan sebesar 0,840 . Koefisen bobot faktor tersebut dikategorikan signifikan pada level 0,05 karena nilai t-Statistik lebih besar dari 1.96 yakni sebesar 23,898. Berdasarkan temuan tersebut maka Hipotesis 3 dalam penelitian ini diterima, yang berarti bahwa pengambilan risiko merupakan refleksi penting dari orientasi kewirausahaan bagi pengusaha perempuan di Kota Malang.

\subsection{Pembahasan}

Keinovasian sebagai hal penting dalam merefleksikan orientasi kewirausahaan bagi pengusaha perempuan di Kota Malang, paling diindikasikan oleh keaktifan pengusaha perempuan dalam mencari metode baru untuk menjalankan bisnis. Keinovasian tidak dapat direfleksikan oleh perbaikan yang berkelanjutan dalam proses produksi serta perhatian yang tinggi atas upaya pengembangan tehnik atau metode dalam menjalankan (memproduksi) barang dan jasa dari usaha yang dikelola pengusaha perempuan. Hal ini bisa disebabkan oleh tipologi usaha yang dijalankan oleh pengusaha perempuan (usaha kecil dan menengah atau SME). Perbaikan yang berkelanjutan dan perhatian atas upaya pengembangan tehnik dalam produksi atau menjalankan bisnis cenderung lebih banyak diterapkan pada organisasi bisnis yang mempunyai skala lebih besar atau telah menggunakan adopsi tehnologi secara maksimal. Sementara tipologi usaha yang dijalankan oleh pengusaha perempuan yang menjadi responden penelitian adalah usaha kecil menengah yang memproduksi oleh - oleh dan atau kerajinan tangan, yang lebih banyak menggunakan pola tradisional dalam memproduksi atau mengolah produk (handmade). Oleh karena itu temuan penelitian mengungkap pentingnya metode baru yang harus diterapkan pengusaha perempuan yang mengelola UKM, meski hal ini belum mengarah kepada upaya perbaikan berkelanjutan (sustainability improvement) dan pengembangan tehnik produksinya.

Meski begitu, berdasarkan fakta di lapangan hal yang paling ditunjukkan oleh pengusaha perempuan adalah melakukan inovasi dalam proses untuk pengelolaan usaha. Inovasi dalam konteks UKM yang dikelola pengusaha perempuan mungkin lebih bersifat inkremental, terutama dalam hal keterampilan teknis yang diperlukan, belum mengarah pada inovasi sistem secara keseluruhan. Fakta bahwa orientasi kewirausahan dapat mempengaruhi kinerja usaha dengan adanya peran proses penciptaan pengetahuan (Li et al, 2008) dapat menjadi catatan penting untuk pengembangan dari UKM yang dikelola pengusaha perempuan. Secara umum karyawan dapat belajar dan bertukar pengetahuan secara kolektif, dan lebih mengerti gaya kewirausahaan pengusaha perempuan dan visi yang diartikulasikan dengan konsep eksplisit dan gagasannya. Praktik dan aktivitas kewirausahaan kemudian diintegrasikan dan disebarluaskan ke seluruh lini bisnis untuk dapat menghasilkan lebih banyak pengetahuan yang bersifat aplikatif ( $\mathrm{Li}$ et al, 2008). Orientasi kewirausahaan dapat diaktualisasikan dalam bentuk tindakan praktis dan mewujudkan pengetahuan menjadi aset berharga dalam memajukan pengembangan produk baru atau kegiatan pemasaran UKM yang dikelola pengusaha perempuan.

Proaktif sebagai hal penting dalam merefleksikan orientasi kewirausahaan bagi pengusaha perempuan di Kota Malang, paling diindikasikan oleh mendorong diri untuk dapat melakukan tindakan preventif dalam mengelola usahanya.Hal ini diperkuat dengan fakta di 
INOBIS: Jurnal Inovasi Bisnis dan Manajemen Indonesia

Volume 2, Nomor 1, Desember 2018

Rois Arifin; Hadi Sunaryo

lapangan yang menunjukkan sikap proaktif yang paling tinggi ditunjukkan oleh tindakan preventif oleh pengusaha perempuan. Usaha kecil menengah dengan aktivitas kewirausahaan yang tinggi dan berarti tampak dari tingkat semangat yang tidak pernah padam karena hambatan, rintangan, dan tantangan. Sikap aktif dan dinamis, termasuk tindakan preventif menyiratkan keinginan yang besar dari pengusaha perempuan untuk mencapai kesinambungan dan atau keberlanjutan dari usaha yang telah dikelola terutama dalam menghadapi turbulensi lingkungan sosial dan ekonomi (Pratono dan Mahmood, 2016).

Pengambilan risiko sebagai hal penting dalam merefleksikan orientasi kewirausahaan bagi pengusaha perempuan di Kota Malang, paling diindikasikan oleh sikap mendorong orang dalam bisnis untuk mengambil risiko. Berkebalikan dengan fakta di lapangan yang menunjukkan bahwa secara pribadi pengusaha perempuan lebih banyak dikenal menekankan eksplorasi dan eksperimen untuk mendapatkan peluang dalam menjalankan usahanya. Pengusaha perempuan yang berani mengambil risiko dapat didefinisikan sebagai pengusaha yang berorientasi pada peluang dalam ketidakpastian konteks pengambilan keputusan (Lomberg et al., 2016). Hambatan risiko merupakan faktor kunci yang membedakan usaha yang dijalankan dengan jiwa kewirausahaan dengan yang tidak.

\section{Simpulan dan Keterbatasan Penelitian}

Pengujian model orientasi kewirausahaan pada pengusaha perempuan yang mengelola UKM produksi oleh-oleh dan kerajinan tangan di Kota Malang menunjukkan bahwa secara umum bahwa seluruh dimensi orientasi kewirausahaan bermakna penting. Hasil penelitian ini turut mengkonfirmasi tentang pandangan bahwa dimensi orientasi kewirausahaan sebagai konstruk yang terpisah bukan sebagai sesuatu konstruk strategik tunggal. Oleh karenanya dalam hubungan kausalitas dengan hasil seperti kinerja usaha, tiga dimensi orientasi kewirausahaan tidak memberi kontribusi yang sama.

Bentuk sikap proaktif menjadi hal terpenting dibandingkan keinovasian dan pengambilan risiko dalam merefleksikan orientasi kewirausahaan pengusaha perempuan. Temuan penelitian mengungkap keinovasian sebagai hal yang dipandang masih kurang penting dan paling rendah penerapannya pada UKM yang dikelola pengusaha perempuan. Sebagai tambahan, hanya dua hal dari bentuk indikator keinovasian yang dianggap tidak sesuai dan tidak berarti penting dalam merefleksikan keinovasian dan orientasi kewirausahaan secara umum.

Secara spesifik, keinovasian dari UKM seharusnya dapat memberi kontribusi pada penawaran produk yang unik, yaitu nilai produk yang berbeda dari pesaingnya. Rendahnya tingkat inovasi dalam orientasi kewirausahaan pengusaha perempuan yang mengelola UKM produksi oleh-oleh dan kerajinan tangan di Kota Malang bisa jadi karena lemahnya upaya dalam mengeksplorasikan gagasan baru dan ikut serta dalam eksperimentasi sebagai faktor utama bagi kesuksesan pengembangan produk baru.

Oleh karena itu para pemangku kepentingan yang terkait yang tertarik meningkatkan kinerja dari UKM produksi oleh-oleh dan kerajinan tangan di Kota Malang dapat memfokuskan pada pengembangan kapasitas inovatif dari pengusaha perempuan dan usaha yang dikelolanya, sehingga dapat mendorong organisasinya lebih inovatif. Selain itu, tipologi UKM menjadi catatan penting tentang bentuk inovasi yang masih belum dilakukan secara maksimal, mempertimbangkan keterbatasan sumber daya dan kapasitas yang dimiliki. Untuk selanjutnya proses penciptaan pengetahuan dalam UKM yang dikelola pengusaha perempuan dapat dipertimbangkan untuk dikaji lebih lanjut dalam konteks penelitian yang berbeda. 
INOBIS: Jurnal Inovasi Bisnis dan Manajemen Indonesia

Volume 2, Nomor 1, Desember 2018

Rois Arifin; Hadi Sunaryo

Penelitian ini mencakup beberapa keterbatasan, antara lain : Pertama, pendekatan empiris bergantung pada tanggapan dari pemilik atau pengelola UKM, sehingga penelitian ini tidak menyelidiki perspektif karyawan di UKM dan pemangku kepentingan lainnya. Kedua, penelitian menggunakan desain cross sectional, yang hanya menangkap fenomena empiris pada satu waktu tertentu. Sehingga desain longitudinal untuk penelitian selanjutnya dapat menjawab keterbatasan ini sekaligus mengungkap fakta empiris lain bagi pengusaha perempuan untuk mengelola faktor kontingensi dalam pengelolaan UKM berdasarkan orientasi kewirausahaannya.

\section{Daftar Pustaka}

Covin, J.G., Green, K.M., \& Slevin, D.P. 2006. Strategic process effects on the entrepreneurial orientationsales growth rate relationship. Entrepreneurship Theory and Practice, 30:57-81.

Covin, J.G. \& Slevin, D.P.1989. Strategic management of small firms in hostile and benign environments. Strategic Management Journal, 10:75-87.

Covin, J., \& Slevin, D.1991. A conceptual model of entrepreneurship as firm behavior. Entrepreneurship Theory and Practice, 16 (1): 7-24.

Covin, J.G., \& Lumpkin, G.T. 2011. Entrepreneurial Orientation Theory and Research: Reflections on a Needed Construct. Entrepreneurship Theory and Practice, 35(5):855872.

Covin, J.G. \& Wales, W.J. 2012. The measurement of entrepreneurial orientation. Entrepreneurship Theory and Practice, 36(4):677-702.

Frank, H., Kessler, A., \& Fink, M.2010.Entrepreneurial orientation and business performance - A replication study. Strategic Business Review 62:175-198.

Hatta, I.H. 2014. Analisis Pengaruh Inovasi, Pengambilan Resiko, Otonomi, dan Reaksi Proaktif Terhadap Kapabilitas Pemasaran UKM Kuliner Daerah di Jabodetabek. Jurnal Manajemen Pemasaran, 8(2) : 90 - 96.

Hughes, M. \& Morgan, R.E. 2007. Deconstructing the relationship between entrepreneurial orientation and business performance at the embryonic stage of firm growth. Industrial Marketing Management, 36:651-661.

Khandwalla, P.N. (1977). Some top management styles, their context and performance. Organization and Administrative Sciences, 7(4) : 21-51.

Krauss, S. I., Frese, M., Friedrich, C., Unger, J. M.2005. Entrepreneurial orientation: A psychological model of success among southern African small business owners. European Journal of Work and Organizational Psychology 14 (3): 315-44.

Li, Y.H., Huang, J.W., Tsai, M.T. 2009.Entrepreneurial orientation and firm performance: The role of knowledge creation process. Industrial Marketing Management, 38 (4):440 $-449$.

Lomberg, C., Urbig, D., St€ockmann, C., Marino, L.D., Dickson, P.H. 2016. Entrepreneurial Orientation: The Dimensions' Shared Effects in Explaining Firm Performance. Entrepreneurship Theory and Practice, 41(6):973-998.

Lukiastuti, F.2012.Pengaruh Orientasi Wirausaha dan Kapabilitas Jejaring Usaha Terhadap Peningkatan Kinerja UKM Dengan Komitmen Perilaku Sebagai Variabel Interviening (Studi Empiris pada Sentra UKM Batik di Sragen, Jawa Tengah). Jurnal Organisasi dan Manajemen, 8/2:155-175.

Lumpkin, G.T., \& Dess, G.G.1996.Clarifying the entrepreneurial orientation construct and linking It to performance. Academy of Management Review, 21/1:135-172. 
INOBIS: Jurnal Inovasi Bisnis dan Manajemen Indonesia

Volume 2, Nomor 1, Desember 2018

Rois Arifin; Hadi Sunaryo

Lyon, D. W., Lumpkin, G. T., Dess, G. G.2000. Enhancing entrepreneurial orientation research: Operationalizing and measuring a key strategic decision making process. Journal of Management 26 (5) : 1055-1085.

Miller, D. (2011). Miller (1983) revisited: A reflection on EO research and some suggestions for the future. Entrepreneurship Theory and Practice, 35(5): 873-894.

Miller, D. \& Friesen, P.H. 1982. Innovation in conservative and entrepreneurial firms: Two models of strategic momentum. Strategic Management Journal, 3 : 1-25.

Miller. D., \& Friesen, P. H.1983. Strategy making and environment: The third link. Strategic Management Journal, 4 : 221-235.

Mintzberg, H. 1973. Strategy-making in three modes. California Management Review, 16(2):44-53.

Pratono, A., Mahmood, R. 2016. Entrepreneurial orientation and firm performance: How can small and medium-sized enterprises survive environmental turbulence?. Pacific Science Review B: Humanities and Social Science, July $2016: 1-7$.

Richard, O. C., Barnett, T., Dwyer, S., \& Chadwick. K.2004.Cultural diversity in management, firm performance, and the moderating role of entrepreneurial orientation dimensions. Academy of Management Journal, 47:255-266.

Tan, J. (1996). Regulatory environment and strategic orientations in a transitional economy: A study of Chinese private enterprise. Entrepreneurship Theory and Practice, 21(1) : 3146.

Voss, Z.G., Voss, G.B., \& Moorman, C. 2005. An empirical examination of the complex relationships between entrepreneurial orientation and stakeholder support. European Journal of Marketing, 39(9/10):1132-1150.

Wicaksono, G., Nuvriasari, A. 2012. Meningkatkan Kinerja UMKM Industri Kreatif Melalui Pengembangan Kewirausahaan dan Orientasi Pasar : Kajian Pada Peran Serta Wirausaha Wanita di Kecamatan Moyudan, Kabupaten Sleman, Propinsi DIY. Jurnal Sosio Humaniora, 3(4):27 - 39.

Wiklund, J. 1999. The sustainability of the entrepreneurial orientation - performance relationship. Entrepreneurship Theory and Practice, 24(1) : 37-48.

Wiklund, J. \& Shepherd, D. 2005. Entrepreneurial orientation and small business performance: A configurational approach. Journal of Business Venturing, 20 : 71-91. 